\title{
Chen Shui-bian: On Independence
}

Jonathan Sullivan* and Will Lowe ${ }^{\dagger}$

\begin{abstract}
Chen Shui-bian achieved an international reputation for his promotion of Taiwan independence. Whilst that reputation may have been well earned, the analyses on which this conclusion is based are frequently flawed in two ways. First, by using an undifferentiated notion of independence, they tend to conflate sovereignty with less threatening expressions of Taiwanese identity and pro-democracy discourse. Second, by failing to take into account the impact of immediate strategic context, analysts ignore a fundamental element of democratic political communication. In our empirical analysis of more than 2,000 of Chen's speeches, we seek to avoid both flaws by unpacking the concept of independence and taking into account Chen's strategic relationship with his primary audiences. Our findings challenge popular portrayals of Chen, but more importantly they have strong implications for policy makers and students of political rhetoric with regard to current and future ROC presidents.
\end{abstract}

During his time as president of the Republic of China (ROC), Chen Shui-bian 陳 水扁 achieved international notoriety for his promotion of "Taiwan independence." With the taut strategic conditions prevailing in the Taiwan Strait, Chen was routinely depicted in international media as being provocative and quixotic. ${ }^{2}$ Nor was his portrayal as an irresponsible adventurer bent on independence limited to popular literature. A classic example of the "reckless adventurer" narrative can be found in Robert Ross's article on "Taiwanese revisionism." Writing in 2006, Ross declared that "Taiwan has taken incremental steps that signal its intention to declare independence" and left no doubt that it was Chen, a "risk acceptant leader" with a "personal commitment to independence," who was

* University of Nottingham. Email: jonathan.sullivan@nottingham.ac.uk

$\uparrow$ Maastricht University. Email: w.lowe@maastrichtuniversity.nl

1 As an indication of this fame, a Lexis-Nexis search of English language news sources between 2003 and 2008 returns 1,390 articles with three or more mentions of Chen in connection with "Taiwan independence."

2 A similar Lexis-Nexis search returns 464 articles in which Chen is associated three or more times with "recklessness" or "danger."

3 Robert Ross, "Explaining Taiwan's revisionist diplomacy," Journal of Contemporary China, Vol. 15, No. 48 (2006), pp. 443-58. For an alternative opinion see Edward Friedman, "Taiwan's independence plot," Issues and Studies, Vol. 42, No. 4 (2006), pp. 67-95. 
instrumental in this process. Ross concluded that "the level of the individual is the most persuasive explanation for Taiwan's revisionism."4

The purpose of this article is not to dispute such characterizations of Chen's presidency. Instead its objective is to develop an operational understanding of Chen's presidential discourse and to explicitly measure the content of his rhetoric. In doing so we will try to demonstrate that the idea that Chen expressed a constant level of independence rhetoric is not supported by systematic large-scale analysis of his speeches. Cross-Strait relations, under any ROC president, involve a multi-layered set of issues and interrelated discourses that should not be reduced to ill defined notions of "Taiwan independence." We argue that a minimum requirement for analysing Chen's discourse is to distinguish language relating to Taiwan sovereignty from less threatening expressions of Taiwanese identity and pro-democracy rhetoric. Furthermore, the majority of commentators disturbed by Chen's seemingly erratic discursive behaviour fail to recognize a fundamental logic of democratic political communication. Democratically elected leaders are obliged to look for support from multiple constituencies to achieve their policy goals. ${ }^{5}$ Chen was no exception, ${ }^{6}$ and since the numerous dimensions of Taiwan's national status involve a complex of issues and multiple stakeholders with whom he had to engage, the content of his statements can be expected to contain substantial variation. Simply put, different constituencies vary in their concerns and politicians are often required to make strategic decisions about which issues to emphasize and what kinds of language to generate in order to appeal to that constituency. ${ }^{7}$ By recognizing that audiences provide the immediate strategic context within which Chen operated and by exploring the variation in the content of his rhetoric over a large number of speeches, this article attempts to give a more balanced picture of Chen's presidential discourse.

\section{Disaggregating Cross-Strait Discourse}

As shown by the excitement that Chen and his predecessor's "provocative statements" generated in Beijing and Washington, the public assertions of the ROC president are a matter of major importance. Under both Lee Teng-hui 李登輝

4 Ross, “Explaining Taiwan's revisionist diplomacy,” p. 456.

5 Philip Converse, "The nature of belief systems in mass publics," in David Apter (ed.), Ideology and Discontent (New York: Free Press, 1964), pp. 206-62; Angus Campbell, Philip Converse, Warren Miller and Donald Stokes, The American Voter (Chicago: Chicago University Press, 1960); V.O. Key, The Responsible Electorate: Rationality in Presidential Voting 1936-1960 (Cambridge, MA: Belknap Press, 1966); Samuel Popkin, The Reasoning Voter (Chicago: University of Chicago Press, 1991); John Zaller, The Nature and Origins of Mass Opinion (New York: Cambridge University Press, 1992).

6 For instance Cal Clark, "The paradox of the national identity issue in Chen Shui-Bian's 2004 presidential campaign: base constituencies vs the moderate middle," Issues and Studies, Vol. 41, No. 1 (2004), pp. 53-86.

7 This is in contrast to a full information spatial politics model with a single homogenous audience, where political actors are expected to gravitate towards a single "median-voter" position. Anthony Downs, $A n$ Economic Theory of Democracy (New York: Harper and Row, 1957); Melvin Hinich and Michael Munger, Analytical Politics (Cambridge: University of Cambridge Press, 1997). 
and Chen, the ROC president was the most volatile actor in cross-Strait relations and for better or worse, rhetoric emanating from the presidential palace came to be interpreted as an indicator of Taiwan's underlying preferences and policy positions. ${ }^{8}$ In the absence of unforeseen developments, the attention and importance attached to Lee and Chen's statements also holds true for Ma Ying-jeou 馬英九, and indeed for any future president. A systematic investigation of Chen Shui-bian's public statements is thus an important undertaking not solely for its historical interest but as an exercise that is relevant for the study of any ROC president's rhetoric.

Our point of departure is the contention that, just as "national identity" measured at the individual level requires separation into its conceptual parts, ${ }^{9}$ so it is necessary to unpack what is meant by "independence" discourse. Drawing on the large body of Taiwan studies literature that has dealt with this issue, we provide a framework for analysing Chen's statements by identifying three salient dimensions: sovereignty, Taiwanese identity and pro-democracy.

\section{Formal independence and Taiwan sovereignty}

One thing that stands out when surveying the literature on cross-Strait relations is that Taiwan scholars seldom appear pre-occupied by the prospect of independence, at least when independence is defined as the formal declaration of an independent Taiwanese state. For example, Shelley Rigger observes that "the idea has become so marginalized that overt promotion of independence within the political arena has all but disappeared." 10 Whether as a result of China's explicit equation of independence with war or because of a positive preference for the status quo, the configuration of Taiwanese public opinion is stable and unequivocally against an immediate declaration of formal independence. ${ }^{11}$ The marginalization of support for independence has effectively rendered the issue "electoral poison." 12 Given the PRC's intractable opposition and the ROC's diplomatic isolation, Taiwan would gain nothing and risk losing its existing autonomy and more, just to make "a futile gesture ignored by the international community." 13 As Edward Friedman puts it, "even if the Taiwan president, after a popular referendum, announced to the world 'I now declare the existence of a sovereign Republic of Taiwan and ask the world community to establish full

8 In reality Chen faced heavy constraints in turning rhetoric into policy outcomes. As Alan Romberg pointed out, "the proposals Chen can carry out would not take him across PRC 'redlines'; those that would, he lacks the wherewithal to carry out." "Recent developments in Taiwan: Politics in commandbut at what cost?" PacNet No. 6 (2006), p. 1.

9 Shelley Rigger, "Social science and national identity: a critique," Pacific Affairs, Vol. 72, No. 4 (1999), pp. 537-52.

10 Shelley Rigger, "Maintaining the status quo: what it means and why Taiwanese prefer it," Cambridge Review of International Affairs, Vol. 14, No. 2 (2001), p. 104.

11 Emerson Niou, "Understanding Taiwan independence and its policy implications," Asian Survey, Vol. 44, No. 4 (2004), pp. 555-67.

12 Dafydd Fell, Party Politics in Taiwan (London: Routledge, 2005), p. 122.

13 Shelley Rigger, "Party politics and Taiwan's external relations," Orbis, Vol. 49, No. 3 (2005), p. 428. 
diplomatic relations,' so what?"14 It is inconceivable that any nation would turn away from the PRC in order to recognize and support a Republic of Taiwan. ${ }^{15}$ Apart from a small minority, elites and voters in Taiwan are well aware of this and, as Friedman concludes, "de jure independence is going nowhere."16

Nevertheless, the sovereignty question constitutes an important dimension of discourse on cross-Strait relations. Alan Wachman observes how the contest to exercise sovereignty over Taiwan has been "displaced to the rhetorical arena where the disputants tangle over slogans, concepts and labels." 17 In this sense, a crucial development within the Democratic Progressive Party (DPP) in the mid-1990s was the ideational and rhetorical shift from the pursuit of a chimerical Republic of Taiwan to Taiwanese self determination within the status quo framework of the ROC. ${ }^{18}$ The basic position is virtually identical to Lee Teng-hui's statement that "the ROC has been a sovereign state since it was founded in 1912 [and] consequently there is no need to declare independence." 19 This "repackaging of independence" made the DPP more credible at the polls ${ }^{20}$ and freed the party to pursue its localization programme once in power without escalating tensions in the Strait to the point of military conflict. ${ }^{21}$ Chao notes that the DPP was able to "redefine the terms of independence by stressing preservation of the status quo over reconstruction of a new entity." 22 This version of "independence" was apparently less threatening to the PRC. How else, asks Kenneth Lieberthal, can we explain the fact that "for more than a decade Taiwan's leaders have declared Taiwan to be an 'independent sovereign country' without dramatic consequences"? ${ }^{23}$ There is also a stronger, though naturally contested, basis for the $R O C^{\prime}$ 's sovereignty claim. ${ }^{24}$

The evolution of the DPP's position is consistent with Lowell Dittmer's observation that "the overall pattern of political movement, whether public opinion or macro political narratives, is from one China to a two sovereign states

14 Friedman, "Taiwan's independence plot," p. 78.

15 For a more detailed vision of the "worst case scenario" see Yu-shan Wu, "Taiwanese nationalism and its implications: Testing the worst-case scenario," Asian Survey, Vol. 44, No. 4 (2004), pp. 614-25.

16 Friedman, "Taiwan's independence plot," p. 76.

17 Alan Wachman, "The China-Taiwan relationship: a cold war of words," Orbis, Vol. 45, No. 4 (2000), p. 699.

18 The salient document in this regard is the "Resolution on Taiwan's Future," adopted at the DPP party congress in 1999. It states among other things that "Taiwan is a sovereign independent country [and] although named the ROC under its current constitution is not subject to the jurisdiction of the PRC."

19 Extracted from Lee's "state to state" interview with Deutsche Welle in 1999. Italics added.

20 Fell, Party Politics in Taiwan, p. 98.

21 The DPP's “discovery" of ROC sovereignty was a significant development, not least because the main thrust of its earlier position was precisely independence from the $R O C$, which many supporters perceived to be inherited from the mainland and inconsistent with Taiwan's historical and political reality. See Stephane Corcuff, "The supporters of unification and the Taiwanisation movement," China Perspectives, Vol. 53 (2005), p. 50.

22 Chien-min Chao, "One step forward, one step backward: Chen Shui-bian's mainland policy," Journal of Contemporary China, Vol. 12, No. 34 (2003), p. 141.

23 Kenneth Lieberthal, "Preventing a war over Taiwan," Foreign Affairs, Vol. 84, No. 2 (2005), p. 54.

24 A more forthright statement in this vein is the argument that, "while Taiwan is definitely independent, it is so, in law, only as the ROC, not as Taiwan." Corcuff, "The supporters of unification and the Taiwanisation movement," p. 50 . 
position." 25 The central feature of this position, which Gunther Schubert calls an "overarching consensus" shared by both major parties, ${ }^{26}$ is that the ROC on Taiwan is an independent sovereign entity and that the ROC state must be maintained. To this end, Taiwan should try to bolster the ROC's sovereignty claim by maintaining its small number of diplomatic allies and expanding its role in international society by applying for membership of international organizations and maintaining substantive links with any country willing to do so. Taiwan should also "avoid picking fights with China, by not directly challenging China's sovereignty claim over Taiwan."27 Like his predecessor, Chen managed to avoid picking the ultimate fight, but his proclamations on sovereignty and explicit rejection of "one China" hardened the PRC's position on Taiwan's participation in the international arena and won him few friends in the United States. Sovereignty was doubtless an important part of Chen's ideology, but international conditions and public opinion were such that the range of potential actions open to him on this front was limited. On the domestic stage, however, in spite of fierce opposition and institutional constraints, Chen enjoyed greater freedom to pursue a nation-building project rooted in a particular conception of national identity.

\section{Taiwan identity}

If sovereignty is the external dimension of Chen's "independence discourse," national identity, specifically Taiwanese identity, is the internal dimension. It is well known that national identity has long been "the dominant cleavage underpinning Taiwan's party situation," 28 and though Chen did not create this situation, his tenure certainly exacerbated it. What distinguished Chen from more moderate elements in the DPP and the domestic opposition was his "insistence on a specific Taiwanese national identity." 29 Though the DPP wriggled free from earlier commitments to Taiwan independence, it retained a preference for advancing an explicitly Taiwanese, as opposed to Chinese, identity for Taiwan. Taiwan identity has an element of ethnic distinction within the domestic context, but more pertinent to the focus of this article is that it also forms the basis of attempts to establish or consolidate, depending on one's viewpoint, Taiwan's distinctiveness from China. Amongst other things this distinctiveness is based on the community of diverse ethnic groups that live in Taiwan and a historical and cultural specificity that makes it quite distinct from the PRC. The degree of separation is maintained by Taiwan's experience as a democracy and by PRC

25 Lowell Dittmer, "Taiwan's aim-inhibited quest for identity and the China factor," Journal of Asian and African Studies, Vol. 40 No. 1/2 (2005), p. 86.

26 Gunther Schubert, "Taiwan's political parties and national identity: the rise of an overarching consensus," Asian Survey, Vol. 44, No. 4 (2004), pp. 534-54.

27 Clark, "The paradox of the national identity issue," p. 79.

28 John Fuh-Sheng Hsieh, "National identity and Taiwan's mainland China policy," Journal of Contemporary China, Vol. 13, No. 40 (2004), p. 479.

29 Schubert, "Taiwan's political parties and national identity," p. 548. 
hostility, particularly its refusal to renounce the use of force and its aggressive efforts to limit Taiwan's activities in the international realm, which many Taiwanese believe should be concomitant with the island's level of economic development and status as a liberal democracy. ${ }^{30}$

However, Chen's project went further than merely emphasizing differences with the PRC. As Daniel Lynch observed in 2004, Chen oversaw an attempt to "imagine a completely new and genuinely autonomous Taiwan," noting that "Taiwan already has territory, a government and a people: the challenge remaining is to construct a strong collective identity." 31 Though the project dominated most of Chen's tenure, particularly after re-election, it was "inhibited domestically by split sub-ethnic identities." 32 Construction of an exclusively Taiwanese national identity at the expense of any residue of Chinese-ness was controversial with Taiwanese who identified politically with Taiwan, but did not necessarily want to deny their Chinese cultural heritage. Nevertheless, and with ever fewer options open to him, Chen pursued his "deliberate nation building effort," 33 enacting aggressive programmes of symbolic Taiwanization and de-Sinification. Without question, China feared the potential of this project to consolidate and normalize Taiwan's de facto separation from the mainland. ${ }^{34}$ Trends in national identity at the individual level support this view, with a majority of Taiwanese claiming Taiwan-centred identities by $2004 .{ }^{35}$ However the rise in Taiwan-centred identifiers did not translate into a preference for formal independence, ${ }^{36}$ another indication that national identity and sovereignty should be treated as distinct, albeit linked, concepts. Indeed Cabestan argues that "Taiwanese nationalism" was fed by the competing identities of domestic sub-ethnic groups, rather than a desire to separate from the Chinese nation. ${ }^{37}$ There is some evidence that Chen and other DPP figures, particularly during the re-election campaign in 2004, sought to tie sub-ethnic identity to preferences on national status. ${ }^{38}$ Similarly, Chen made a major effort in both of his presidential campaigns to frame himself as the embodiment of an essential Taiwan. ${ }^{39}$

30 Jean-Pierre Cabestan, "Specificities and limits of Taiwanese nationalism," China Perspectives, Vol. 62 (2005), p. 37.

31 Daniel Lynch, “Taiwan's self-conscious nation-building project,” Asian Survey, Vol. 44, No. 4 (2004), p. 514

32 Dittmer, "Taiwan's aim-inhibited quest for identity and the China factor," p. 72.

33 Lowell Dittmer, "Taiwan and the issue of national identity," Asian Survey, Vol. 44, No. 4 (2004), p. 475.

34 Wachman, "The China-Taiwan relationship."

35 T.Y. Wang and I.C. Liu, "Contending identities in Taiwan: implications for cross-Strait relations," Asian Survey, Vol. 44, No. 4 (2004), pp. 568-90.

36 The link between micro (individual identity) and macro-politics (political movements) is perceptively examined in Niou, "Understanding Taiwan independence and its policy implications"; Yu-shan Wu, "Taiwanese nationalism and its implications"; Wang and Liu "Contending identities in Taiwan."

37 Cabestan, "Specificities and limits of Taiwanese nationalism," p. 34.

38 Clark, "The paradox of the national identity issue."

39 For a perceptive account of Chen's "Son of Taiwan" campaign rhetoric in 2000, see Shelley Rigger, From Opposition to Power: Taiwan's Democratic Progressive Party (Boulder, CO: Lynne Rienner, 2001). 


\section{Democracy}

The ideas of democracy, ethnic justice and self determination have been intertwined since the first stirrings of democratization in the 1970s. Many opposition activists, who joined in 1986 to form the DPP, explicitly linked the goal of democratization to "the issue of Taiwanese identity and the principle of selfdetermination."40 In this way the Dangwai 黨外 and subsequently the DPP were able to gather support for "ethnic justice internally and independence from China externally" 41 whilst simultaneously countering the KMT's successful socio-economic programmes and uniting activists with disparate agendas. In the 1970s and 1980s the ruling KMT also saw democratization not only as a "pressure valve" to release growing discontent but as a crucial means of legitimating their rule both domestically and abroad. Thus there has long been a "symbolic dimension to democratization" in Taiwan. ${ }^{42}$ Naturally, Taiwan's democracy is also a source of pride and identification for many Taiwanese; another practical and psychological element in their estrangement from the PRC.

Given this background, and the context of Chen's initiation into politics as a defence attorney for the Meilidao 美麗島 activists, it was no surprise that, as a presidential candidate and president, he campaigned vigorously for democratic and institutional reforms. ${ }^{43}$ Indeed, during his re-election campaign Chen portrayed himself as a democratic champion, juxtaposed with opponents who were framed as denying the people direct democracy. Part of Chen's emphasis on institutional reforms was purely practical: Taiwan's experience of divided government, particularly during the early part of his first term, was a complete and debilitating breakdown of executive-legislative relations. ${ }^{44}$ The remainder was perhaps part genuine commitment to democratic reform combined with making use of supposed democratic reforms for political ends, both domestically and with respect to China. Accusations of heavy-handedness and financial corruption during Chen's second term did not help the perception of the balance of these two motivations.

Two of Chen's "democratic" initiatives, referenda and constitution reform, were the cause of much controversy. The "defensive referendum" held in 2004 has been decried as a ploy to build momentum for Chen's re-election bid and

40 Tse-Min Lin, Yun-Han Chu and Melvin J. Hinich, "Conflict displacement and regime transition in Taiwan: a spatial analysis," World Politics, Vol. 48, No. 4 (1996), pp. 453-81.

41 Clark, "The paradox of the national identity issue," p. 74.

42 Stephane Corcuff, "The symbolic dimension of democratization and the transition of national identity under Lee Teng-hui," in Stephane Corcuff (ed.), Memories of the Future: National Identity Issues and the Search for a New Taiwan (Armonk, NY: M.E. Sharpe, 2002). In light of Chen's troubled tenure and a legacy further tarnished by post-presidency corruption charges, it is easy to forget the symbolic magnitude of his surprise victory in 2000. For a stirring account of those momentous times see Rigger, From Opposition to Power.

43 Rigger, From Opposition to Power.

44 John F. Copper, "Taiwan: democracy's gone awry?” Journal of Contemporary China, Vol. 12, No. 34 (2003), pp. 145-62; Yun-han Chu, "Taiwan's year of stress," Journal of Democracy, Vol. 16, No. 2 (2005), pp. 43-58. 
to increase the feeling of danger from China's missile build-up across the Strait, rather than promoting the stated goal of "direct democracy." 45 Whilst Chen was assiduous in framing referenda as a democratic reform giving "power to the people," given the content of the defensive referenda held in 2004 and 2008 concurrent with presidential elections - from which the DPP would theoretically gain advantage by ensuring the salience of the accompanying democracy and national identity discourses on which they relied for electoral success - one cannot ignore the probability that referenda were used as election tools. ${ }^{46}$ Another suspicion, albeit one we find less convincing, was that referenda were "a ploy to take Taiwan one step further towards outright independence by introducing a procedure through which constitutional changes could be sanctioned." ${ }^{47}$ Constitution reform was similarly framed as a crucial institutional reform, one that was undeniably needed. ${ }^{48}$ Yet when Chen made writing a new constitution the goal for his last two years in office, it raised considerable anxiety that he was "gearing up to formally cement the achievements of the localization movement," perhaps by touching on the taboo constitutional issues of sovereignty and territory. 49

\section{Audiences as an Indicator of Strategic Context}

Taiwan under Chen Shui-bian was the most dynamic actor in cross-Strait relations. Like his predecessor Lee Teng-hui, Chen apparently employed "creeping independence and provocative brinkmanship [to] redefine the direction and purpose of change." ${ }^{50}$ In this sense Taiwan played a clear role in setting the cross-Strait political agenda and was largely responsible for the cyclical trend in relations that veered between acceptable stalemate and periodic spikes in tension. ${ }^{51}$ After displaying moderation and flexibility in the first two years of his tenure, ${ }^{52}$ beginning in the summer of 2002 Chen "reprised Lee's pattern of provocative statements." 53 A second element to Chen's discourse was that it was highly erratic, veering between opposing positions, sometimes from one speech

45 Mily Kao, "The referendum phenomenon in Taiwan," Asian Survey, Vol. 44, No. 4 (2004), pp. 591-613; Mikael Mattlin, "Referendum as a form of zaoshi," Issues and Studies, Vol. 40, No. 2 (2004), pp. 15585. We should remember however that provision for referenda was written in the ROC Constitution and the legislation that activated article 136 was a KMT sponsored bill passed in a legislature controlled by the KMT and its allies.

46 Ibid. Although holding referenda concurrent with presidential elections was clever, particularly in 2004, it should also be noted that this it is not unusual in other democracies, usually for cost-cutting purposes.

47 Mikael Mattlin, "Same content, different wrapping: cross-Strait policy under DPP rule," China Perspectives, Vol. 56 (2004), p. 29.

48 Rigger, "Party politics and Taiwan's external relations," p. 422; Flemming Christiansen, "Putting Taiwan's constitution on the agenda," European Association of Taiwan Studies, University of London, April 2004, p. 1.

49 Mattlin, "Same content, different wrapping," p. 33

50 Dittmer, "Taiwan's aim-inhibited quest," p. 87.

51 Steven Goldstein, "The Taiwan Strait: a continuing status quo of deadlock?" Cambridge Review of International Affairs, Vol. 15, No. 1 (2002), p. 85.

52 Joseph Wu, "Political earthquake and aftershocks: the DPP after the 2000 presidential election," Journal of Contemporary China, Vol. 11, No. 33 (2002), p. 638.

53 Dittmer, "Taiwan and the issue of national identity," p. 478. 
to the next. As Lieberthal observed, "Chen has created a record that seems to support almost any position on the spectrum." 54 Though it is hard to argue with Sheng's depiction of Chen's eclectic statements as "ambiguous, evasive and contradictory," 55 the concept of "strategic ambiguity" is perhaps more useful. Cal Clark notes two discrete facets of Chen's strategically ambiguous statements: elucidating different positions at different times, and making different appeals on the same issue to disparate constituencies. ${ }^{56}$ Whilst this apparent inconsistency might be damning, in fact these two patterns are consistent with democratic politics in almost any context. Issues and policy stances evolve, problems and new actors emerge, and politicians have no choice but to engage with and appeal to a wide range of stakeholders with varied agendas. ${ }^{57}$

Given this fundamental feature of bureaucratic and electoral politics, we hypothesize that the content of Chen's speeches on sovereignty, Taiwan identity and democracy may vary according to the particular strategic relationship that he has with his immediate audience. Specifically, Chen will modify the content of any speech towards the perceived preference of his primary audience. Naturally speeches may be expected to reach other audiences, ${ }^{58}$ perhaps ones that do not share the same preferences as the primary audience. There is a risk therefore that any advantages gained by "playing to the crowd" might be cancelled out when the same message reaches another audience. In this scenario, the safest option for a speaker would be to pitch the speech in a way that neither fully enthused nor completely enraged both audiences. ${ }^{59}$ We do not deny the likelihood of Chen's speeches reaching audiences other than the primary one he was addressing. However we do argue that the probability of this happening falls short of inevitability, freeing Chen to some extent to adjust the content of his speeches in accordance with his primary audience. We make this claim based on the observation that the majority of Chen's speeches received little television or print coverage. They were made available online, but we feel confident that the information costs incurred to find, access and process the transcripts would deter all but the most dedicated. Furthermore, the advantage of the method we

54 Lieberthal, "Preventing a war over Taiwan," p. 54.

55 Lijun Sheng, China and Taiwan: Cross-Straits Relations under Chen Shuibian (New York: Zed Books, 2002), p. 123.

56 Clark, "The paradox of the national identity issue," p. 80.

57 Jeffrey Cohen, "Presidential rhetoric and the public agenda," American Journal of Political Science, Vol. 39, No. 1 (1995), pp. 87-107; George Edwards III and B. Dan Wood, "Who influences whom? The President, Congress and the media," American Political Science Review, Vol. 93, No. 2 (1999), pp. 327-44; Calvin Mouw and Michael Mackuen, "The strategic agenda in legislative politics," American Political Science Review, Vol. 86, No. 1 (1992), pp. 87-105; William Riker, The Art of Political Manipulation (New Haven: Yale University Press, 1986).

58 Indeed there is tentative evidence to suggest that Chen, and Lee before him, purposefully used a parochial stage to project a message to a much wider audience. Lin finds that of 40 "key speeches" delivered between 1992 and 2005, the majority of the ones that emphasized "Taiwan's independent sovereignty or protested PRC aggression" used informal occasions to do so. Jih-wen Lin, "Uncovering the informal dimensions of Taiwan's cross-Strait policy-making," 34th Sino-American Conference, University of Virginia, 2005, p. 9.

59 Downs, An Economic Theory of Democracy. 
introduce below is that if our argument and assumptions are fundamentally misguided, the data will unequivocally reveal our mistake.

The significant variation in the kinds of relationships Chen "enjoyed" with business interests, the military, his own party, indeed different factions within the DPP, the foreign media, pro-independence groups overseas, diplomatic allies and so on, ${ }^{60}$ reinforces our decision to treat the primary audience as a strategic contextual indicator. Unavoidably, as president in a democratic society, Chen was obliged to appeal to, mobilize and persuade a wide range of actors whose positions on, for example, cross-Strait relations varied. It would be sensible, indeed rational, therefore, if Chen decided to modify the content of his speeches to some extent, to account for this strategic context. Our argument leads us to believe that it was not a coincidence that Chen's "one country on each side" speech was delivered to a pro-independence support group overseas. Nor was it a matter of chance that Chen's inauguration speeches, where we can assume that other international actors were the de facto audience, were noted for their comparatively moderate content.

\section{Methods and Data}

In this study we use computer-assisted content analysis (CCA) ${ }^{61}$ to identify the presence and estimate the amount of presidential language that reflects our three discursive categories of sovereignty, identity and democracy. CCA assumes that theoretically relevant categories of content are not directly observed, but that particular words and phrases reflect them in a systematic way. Specifically, the speaker's choice of words and the frequency with which they are used provide multiple indicators of latent content. Any particular word or phrase may be an unreliable indicator of a complex concept, but when such indicators are combined into a theoretically informed category structure to form a content analysis dictionary, this can generate a reliable mechanism for tapping content. ${ }^{62}$ Political speeches are well suited to CCA because the speaker cannot make strong assumptions about the extent to which an audience shares the nuances of their vocabulary choices. One solution to this problem is thus for the speaker to use relatively unambiguous keywords and simple imagery. CCA has been successfully applied to political party manifestos, parliamentary speeches and even legal briefs. ${ }^{63}$

Naturally CCA cannot replicate the nuances of an in-depth discourse analysis, but it does have two important advantages. First, a CCA dictionary is

60 Saša Istenič, "Taiwan’s business communities in mainland China: contesting influence over cross-Strait economic policy," Leeds East Asia Papers, No. 65 (2004); Elizabeth Freund Larus, "Taiwan's quest for international recognition," Issues and Studies, Vol. 42, No. 2 (2006), pp. 23-52; Catherine Lin, "Taiwan's overseas opposition movement and grassroots diplomacy in the United States: the case of the Formosan Association for Public Affairs," Journal of Contemporary China, Vol. 15, No. 46 (2006), pp. 133-59; Jih-wen Lin, "Uncovering the informal dimensions of Taiwan's cross-Strait policy-making."

61 Roel Popping, Computer-Assisted Text Analysis (Thousand Oaks: Sage, 2000).

62 Kimberley Neuendorf, The Content Analysis Guidebook (Thousand Oaks: Sage, 2002).

63 Michael Laver, Ken Benoit and John Garry, "Extracting policy positions from political texts using words as data," American Political Science Review, Vol. 97, No. 2 (2003), pp. 311-31. 
transparent and replicable. Second, it is possible to apply CCA on a much larger scale. This was an important consideration for us; in the period under investigation Chen gave 2,236 speeches over the course of 2,255 days.

\section{Measures of sovereignty, identity and democracy}

Our three categories were determined by literature review as outlined above. The sovereignty category is intended to cover references to Taiwan's existing independent status, its claim to sovereignty, boundary distinctions between Taiwan and China, and advocacy of actions that reinforce these ideas, such as strengthening the sovereignty claim by expanding Taiwan's international role and writing a new constitution. The national identity category covers signifiers of a distinct collective identity based on common points of identification, references to a distinctive and predominantly hostile "other," and endorsements of or duties to the identifying collectivity. The democracy category covers references to democratic achievements and the existence of rights and freedoms. We privilege Chen's own framing of the referendum and constitution reform issues by including them in the democracy category along with other proposed democratic reforms. Whilst we acknowledge that these two issues have been interpreted as impinging on sovereignty ${ }^{64}$ and could be included in our sovereignty category, we also note that Chen was assiduous in decoupling referenda and constitution reform from sovereignty. ${ }^{65}$

We selected indicators of these three categories inductively through a manual analysis of a sample of 200 of Chen's speeches. Table 1 shows our framework with example indicators. The dictionary contains 120 patterns, 45 each in the sovereignty and identity categories and 30 in the democracy category. ${ }^{66}$ Purely for the purpose of comparison we also constructed an economics category. The economics dictionary is made up of 20 generic economic terms such as "banking" and "stock market" and in this article we attach no theoretical or substantive importance to them. ${ }^{67}$

\section{Data}

In this article we analyse the 2,236 speeches given by Chen Shui-bian between 7 June 2000 and 18 October 2006 that were available at time of writing. ${ }^{68}$ The

64 Kao, "The referendum phenomenon in Taiwan;" Christiansen, "Putting Taiwan's constitution on the agenda," These authors also note that referenda were conceived as a means for Chen to bypass the institutional gridlock created by divided government.

65 See for instance Shelley Rigger, "Taiwan in 2003," Asian Survey, Vol. 44, No. 1 (2004), p. 187. We intend the empirical analysis to demonstrate, at least, that this reading of the referendum and constitutional reform issues is reasonable.

66 To some extent the construction of any content dictionary requires subjective decisions about the connotations of word and phrase content in a complex discourse (as indicated by the discussion of referenda and constitutional reform above). Our dictionary is thus not intended to be the final word on textual indicators of the three categories.

67 Subsequent work will, however, explore the economic integration aspect of cross-Strait discourse.

68 Between 20 March and 7 June 2000, three Chen speeches were available, including one as president-elect and his first inauguration. Though these are obviously important speeches, the consistent record of President Chen's public speeches did not begin until 7 June 2000. 
Table 1: Organization of Dictionaries

\begin{tabular}{|c|c|c|}
\hline Category & Example patterns in English & Selected search entries \\
\hline Sovereignty & $\begin{array}{l}\text { Taiwan sovereignty, Taiwan is sovereign } \\
\text { and independent, Taiwan is an } \\
\text { independent/complete/normal country, } \\
\text { Taiwan is a country, equality with } \\
\text { China, one Taiwan one China, one side } \\
\text { one country, special state to state } \\
\text { relations, Taiwan is not China, } \\
\text { national borders, Taiwan's own road, } \\
\text { go our own way, all new Taiwan } \\
\text { constitution, name rectification, apply } \\
\text { to UN/WHO, diplomatic/international } \\
\text { space, ... }\end{array}$ & $\begin{array}{l}\text { 台灣主權, 主權獨立, 獨立的國家, } \\
\text { 完整的國家, 正常的國家, 台灣是 } \\
\text { 一個國家,一臺一中, 一邊一國, } \\
\text { 特殊國與國關係, 台灣不是中國, } \\
\text { 國家 疆域, 台灣自己的路, 走我 } \\
\text { 們台灣的路, 全新憲法, 台灣新憲 } \\
\text { 法, 以台灣名義申請, 外交空間, } \\
\text { 國際空間, 尊箃平等... }\end{array}$ \\
\hline $\begin{array}{l}\text { National } \\
\text { identity }\end{array}$ & $\begin{array}{l}23 \text { million citizens, the Taiwan nation, } \\
\text { our land, our future, our history, our } \\
\text { country, new Taiwanese, Gemeinshaft; } \\
\text { China's weapons, united front, military } \\
\text { threats, diminish Taiwan, eat up } \\
\text { Taiwan, the other side; protect Taiwan, } \\
\text { Taiwan stand up, Taiwan first, love } \\
\text { Taiwan, God bless Taiwan, ... }\end{array}$ & $\begin{array}{l}\text { 兩千三百萬人民, 台灣人民, 台灣民 } \\
\text { 族, 台灣這塊土地, 台灣的前途, } \\
\text { 我們的國家, 台灣主體, 台灣意 } \\
\text { 識, 新台灣人, 共同體, 和諧, 中共 } \\
\text { 武力, 中國的武器, 中國的統戰, } \\
\text { 武力的恐嚇, 矮化, 吃掉台灣, 對 } \\
\text { 岸, 顧台灣, 台灣站起來, 台灣優 } \\
\text { 先, 台灣第一, 愛台灣, 守護台灣, } \\
\text { 天佑台灣... }\end{array}$ \\
\hline Democracy & $\begin{array}{l}\text { Democratization, democratic reforms, } \\
\text { shake off authoritarianism, liberal } \\
\text { constitutional system, human rights, } \\
\text { citizen rights/freedoms, referendum, } \\
\text { amend/reform the constitution, ... }\end{array}$ & $\begin{array}{l}\text { 民主改革, 民主化, 民主自由, 戒嚴, } \\
\text { 獨裁, 威權, 人權, 言論自由, 政治 } \\
\text { 權利, 出版自由, 公民自由, 人民 } \\
\text { 的權利, 憲政體制, 公投, 公民投 } \\
\text { 票, 修憲, 憲改... }\end{array}$ \\
\hline
\end{tabular}

speeches were downloaded from the Office of the President website, ${ }^{69}$ verbatim and in Chinese, using computer scripts. The texts were then converted into machine-readable form for subsequent analysis. To construct the content dictionary we use the Yoshikoder, ${ }^{70}$ an open-source software package developed by the second author. ${ }^{71}$ The Yoshikoder is a desktop application that runs on any operating system and can deal with text documents in any natural language.

In addition to the content of the speeches, we are also interested in a strategic dimension, that is, Chen's decision to emphasize or de-emphasize language related to a certain category in accordance with his relationship to a particular audience. We have again drawn on the literature as a guide to the type of groups Chen had to engage and their possible different interests and agendas relating to cross-Strait relations. We identified 34 different groups which we aggregate into ten broad categories. These are shown in Table 2, with examples of finer grained audience distinctions. With audience categories established, we assigned an

69 http://www.president.gov.tw.

70 http://www.yoshikoder.org.

71 Will Lowe, "Yoshikoder: an open source multilingual content analysis tool for social scientists," APSA Annual Meeting, Philadelphia, 2006. 
Table 2: Audience Categories

\begin{tabular}{|c|c|c|}
\hline Broad audiences & Example narrow audiences & Code \\
\hline $\begin{array}{l}\text { National Day, } \\
\text { New Year }\end{array}$ & Includes 1 January and Chinese New Year speeches & $n d n y$ \\
\hline Allies & Diplomatic allies, heads of state and other political leaders & alli \\
\hline Diaspora & Taiwan independence groups overseas, Diaspora groups & dias \\
\hline $\begin{array}{l}\text { Domestic } \\
\text { non-political }\end{array}$ & $\begin{array}{l}\text { School children and students, sports men and women, cultural } \\
\text { groups, scientists, women's groups, environmentalists }\end{array}$ & domn \\
\hline Domestic political & $\begin{array}{l}\text { DPP party, policy makers, foundations, campaign supporters, } \\
\text { local media interviews }\end{array}$ & domp \\
\hline Economic & $\begin{array}{l}\text { Regional economic organizations, Taishang (台商), Taiwanese } \\
\text { business people, chambers of commerce }\end{array}$ & econ \\
\hline Foreign dignitaries & $\begin{array}{l}\text { Politicians of non-diplomatic allies, scholars, cultural leaders } \\
\text { from non-allied countries Taiwan/overseas }\end{array}$ & fdig \\
\hline Foreign media & Interviews with international publications & fmed \\
\hline Military & All branches of armed forces and coastguard & mili \\
\hline $\begin{array}{l}\text { Other formal } \\
\text { speeches }\end{array}$ & Inauguration speeches, addresses to the nation & form \\
\hline
\end{tabular}

audience to each speech using information attached to the speeches provided by the Office of the President. ${ }^{72}$

Figure 1 shows the proportion of speeches that Chen gave to different audiences. Domestic non-political audiences constituted approximately half of his speaking engagements, with the smallest amount of attention paid to foreign media $(f m e d)$. The number of speeches to overseas support groups (dias) is also very small. This distribution forms the background to understanding the importance of strategic factors in Chen's discourse, because it is partly on the basis of his engagements with foreign media and pro-independence groups that analysts formed their perceptions of his positions. ${ }^{73}$ If Chen's emphases on sovereignty, Taiwan identity and democracy are different when faced with a less rare audience then we may reasonably conclude that it is his opinions to pro-independence groups that need to be discounted in favour of those to local audiences with whom he more frequently engaged..$^{74}$

Although it is not the central focus of the article, we also suspect that Chen may have altered the content of his speeches in reaction to important external

72 Exceptionally, in the case of "New Year and National Day" and other formal speeches, such as inaugurations, we coded the form of the speech rather than the audience.

73 At this point we should acknowledge that our strategic argument is under-determined by the available data, by which we mean that our assessment of Chen's discursive behaviour is more difficult in the absence of comparative data. Unfortunately, speeches made by other political figures in Taiwan, e.g. in the opposition, were not available in anything like the same abundance as Chen's. Similarly, our argument about audiences is weakened by the absence of data on the positions and preferences of these groups. In effect we are limited to the inference that Chen's relationship with these groups varied, but the degree and direction of this variation we leave to future work.

74 By this statement we do not mean to imply that all audiences (and all speeches) are equally important. However, in our large-scale analysis we treat audiences as separate effects to avoid the problems, discussed in the introduction, of arbitrarily attaching importance to select audiences. 
Figure 1: Proportion of Speeches to Different Audiences

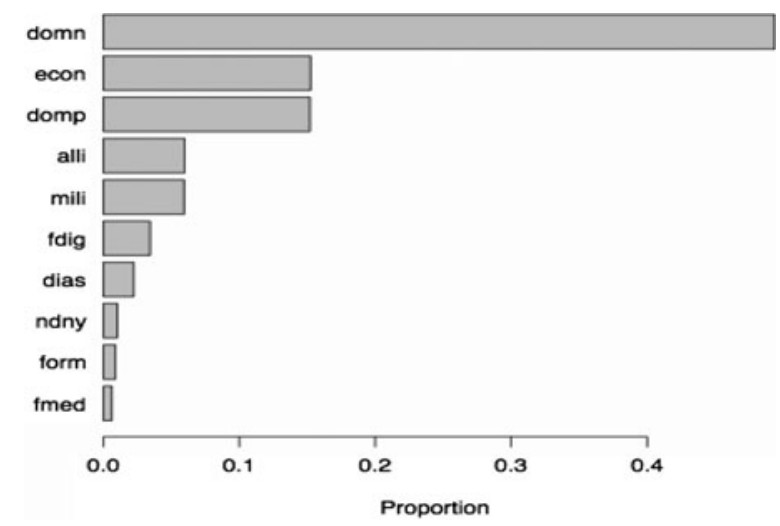

events. To test this supplementary hypothesis we analysed speech content relative to a set of international and domestic political events that we considered might affect his emphasis on our three discursive categories. Initially we used 21 events such as presidential and legislative elections. Of these 21 events only three had a discernable (and statistically significant) impact on the levels of our categories: Hu Jintao and Wen Jiabao's accession to the PRC leadership, the passing of the anti-secession law, and Chen's re-election. These three events are thus included in the following analysis.

\section{Results and Discussion}

The first question we are interested in is the frequency with which Chen makes reference to sovereignty, Taiwan identity or democracy. To see how often each of the three categories is covered in a speech it is sufficient to code whether at least one pattern from a category is matched by any sentence in a speech - a "mention." If a speech has mentions of a category then we can infer that the topic was addressed, although we cannot yet say how much coverage it was subsequently given. Figure 2 shows the results of a logistic regression model of mentions over time for each category. Each line in the figure is a fitted probability of mentioning one of our three categories, and, for comparison, general economic themes. Although we are ultimately interested in the effects of individual audiences, we first aggregate all audiences to show the general category trends over time. The three external events that served to raise or lower the probability of Chen mentioning each category are shown as labelled vertical lines at the appropriate point in time. The vertical axis indicates the probability of any speech containing any one of the search terms in our content dictionaries.

Figure 2 shows that the probability of Chen mentioning three of the four categories is high and increasing over time. His speeches are least likely to contain 
Figure 2: Probability of Mentioning Any One Category

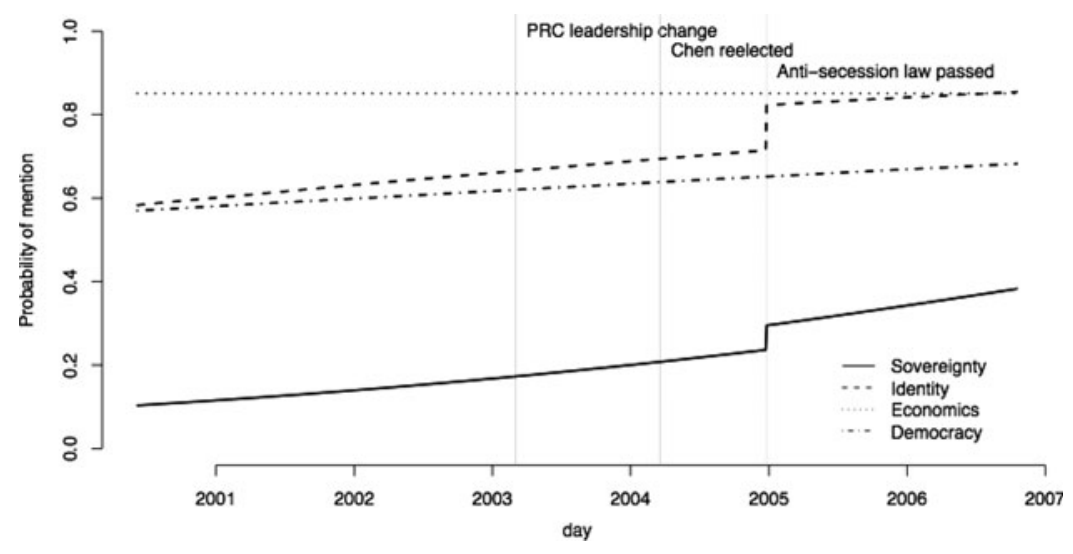

references to the sovereignty issue, but the probability of a mention does increase with time. At the beginning of his term about 10 per cent of speeches mention the topic, but by the time he is re-elected this has more than doubled. There is also a discernable bump in sovereignty talk after the anti-secession law passed, although we can't be sure that this is uniquely attributable to this event. By the end of our time period the proportion of speeches touching on sovereignty is approaching 40 per cent. In contrast, democracy and Taiwan identity are mentioned in approximately 60 per cent of speeches when Chen takes office and this proportion rises slowly at a similar rate until the anti-secession law is passed, when identity issues jump to being mentioned in 80 per cent of speeches. There is a constant 80 per cent chance of any of Chen's speeches mentioning economics, although we show below that this belies a decreasing emphasis on the topic. Including the economics category here is intended to show that increases in our three main categories are not a result of Chen simply talking more. ${ }^{75}$

Examining mentions is a measure of how often Chen covers one of the categories, but we are more interested in how much emphasis he subsequently provides. To see this, we examine the proportion of each speech devoted to each category. Figure 3 shows the results of a similar logistic regression model fitted to the amount of sentences in each speech attributable to each of our categories. Again, we measure this over time, include external events and aggregate the audiences. The vertical axis shows the proportion of sentences in any speech that contain words or phrases in our content dictionary.

It is clear that the proportions involved are small. At its highest point, words and phrases in the democracy category make up just 5 per cent of any speech, nearly doubling from just under 3 per cent at the beginning of the period.

75 In fact Chen's speeches do get longer over the period, so to take account for this and avoid biasing the results, all of our models are normalized by the length of each speech. 


\section{Figure 3: Proportion of Matched Patterns in Each Category}

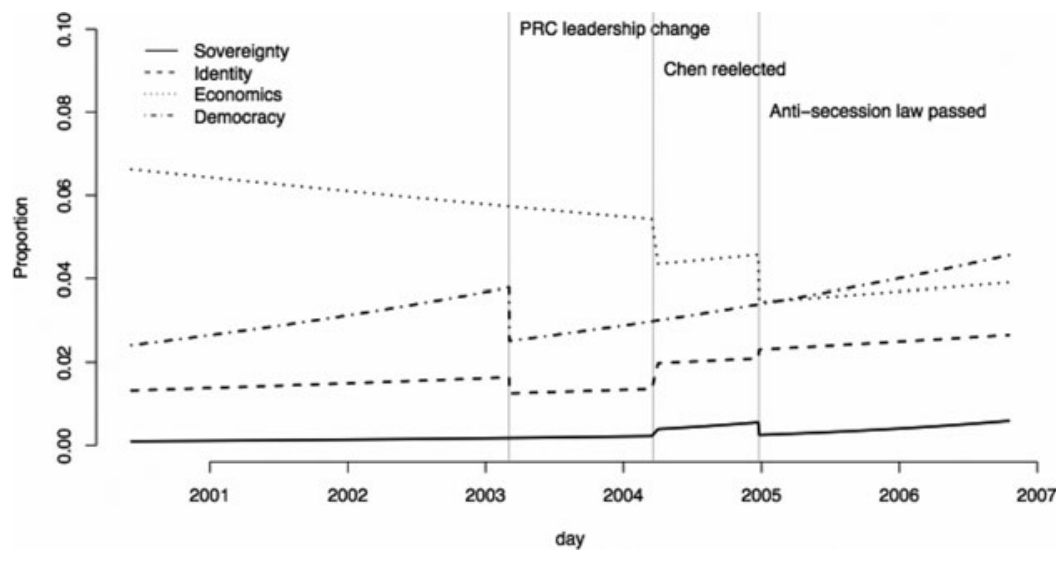

However, given that not all speeches can be solely about the virtues of democratic governance, these proportions may actually be quite high. Nevertheless it is clear that sovereignty issues take up the smallest proportion of any of Chen's speeches: on average less than 1 per cent. Interestingly, external events have more effect on the emphasis Chen places on each category than on whether or not he decides to mention them. For example, we see all of the accumulated increase in the proportion of each speech concerning democracy removed after the change of leadership in China. Chen's re-election generates a brief increase in both Taiwan identity and sovereignty, but the subsequent anti-secession law has the opposite effect, leading him to de-emphasize sovereignty topics and slightly increase the proportion of Taiwanese identity rhetoric. Finally, although Figure 2 showed a constant high probability of mentioning economic themes, Figure 3 reveals a steady decrease in the proportion of each speech devoted to economics. This decrease is hastened in Chen's second term, and again on the passing of the anti-secession law.

\section{Audience effects}

The previous analyses aggregated all audience types in order to show large-scale variation in our categories. However we are also interested in the effects of individual audiences on the content of Chen's speeches. In the subsequent analysis, we concentrate on the proportion of each speech devoted to each category over time, separated by different audiences. If Chen's message is consistent, regardless of the audience he is addressing, then there should be, at most, random variation in the proportion of each speech he devotes to each category. Over more than 2,000 speeches such as we analyse here, random variation would average out, recreating in the figures below the same shape as the aggregated lines shown in Figure 3. If that were the case, our argument about Chen adjusting the content of speeches to different audiences would fall down. 
The next three figures show the results of fitting logistic regression models to the proportion of each category. This is done over time and disaggregates audiences. The vertical axis indicates the proportion of sentences in a speech with indicators in our content dictionaries. Contrary to the previous two figures, for clarity of interpretation we do not include external events, but this does not affect our argument. ${ }^{76}$

Figure 4 deals with sovereignty. Far from averaging out to replicate the aggregate proportion, each audience has a visible effect. Moreover this effect is highly robust. Audience effects are statistically significant in all of the underlying models presented in this section, a strong indication that we are looking at systematic rather than random variation. Overall, the proportion of each speech devoted to sovereignty increases visibly over time, from a uniformly low level when he took office. This suggests that Chen did indeed become more preoccupied with sovereignty over time. In addition to this general increase, however, Chen's audiences have a strong effect in determining the extent of the increase. From highest to lowest proportion, we see that speeches to foreign media and Diaspora groups contain the largest amount of sovereignty discourse. Domestic non-political and economic audiences receive the least. Since around two-thirds of Chen's speeches were addressed to these latter two audiences, it is clear that the aggregated proportion line in Figure 3 has been strongly dampened by the block of speeches given to domestic non-political and economic audiences. Consider that the average proportion of sovereignty language for all audiences together was around one-tenth of a per cent, whereas foreign media and Diaspora groups hear between 1.7 and 1.9 per cent. In short, and as we predicted, there are reliable differences in emphasis in Chen's speeches to different audiences. Specifically, foreign media and pro-independence groups overseas, which constitute a relatively small proportion of Chen's primary audiences, receive much more sovereignty language. ${ }^{77}$

We now examine whether the same degree of audience effect holds for Taiwan identity content (Figure 5). Audience effects again have a demonstrable (and again, in statistical terms, robustly significant) effect on the proportion of Taiwan identity language in Chen's speeches. Again we can infer that the large number of economic and domestic non-political audiences, who get the least amount of identity discourse in their speeches, dampened the aggregated proportion line in Figure 3. Interestingly, Chen reserved for New Year, National Day and other formal speeches

76 This is because external events enter each model additively and raise or lower all audiences' fitted proportions together; there were no significant interactions. By contrast, our argument depends only on the relative proportions of each category per audience which all remain the same, rather than their absolute values.

77 It should be noted that whilst the probability of Chen mentioning indicators of sovereignty appears to be extremely low, language-use norms dictate that the resting levels of category counts for complex concepts is always likely to be low. George Zipf, Human Behavior and the Principle of Least Effort (New York: Hafner, 1965 [1949]). 
Figure 4: Proportion of Sovereignty Language, by Audience

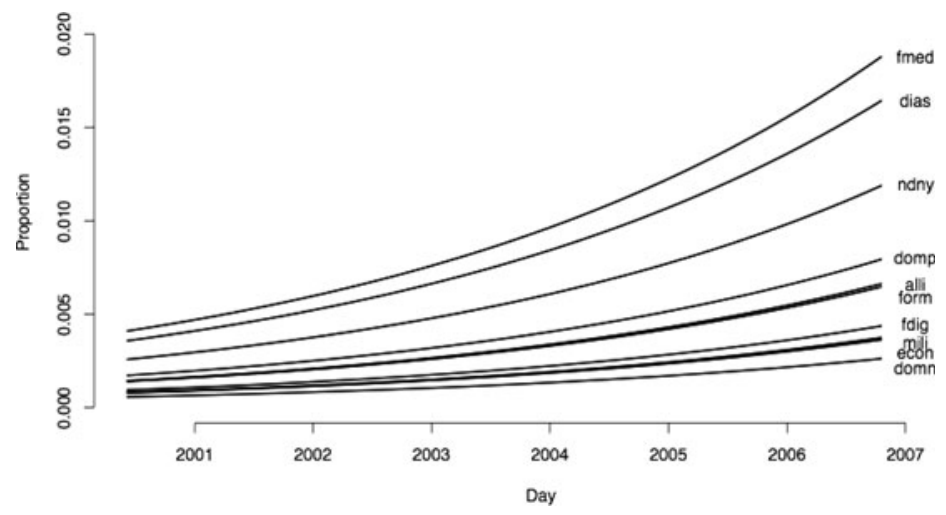

the greatest proportion of Taiwan identity language. This is not surprising, in that these occasions afforded him the highest profile opportunity to promote the "Taiwanization" agenda at the forefront of his administration.

Finally we turn to pro-democracy language. Figure 6 once again shows that individual audiences have a strong effect on the proportion of democracy content. In a similar way to the sovereignty and Taiwan identity themes set out above, domestic non-political and economic audiences, along with the military, receive the lowest proportion of democracy content. By contrast, democracy is an almost constant theme in foreign media appointments, accounting for between 11 and 13 per cent of any such engagements throughout the period. This finding is in keeping with Chen's motivation to project Taiwan's democratic successes to the world, in contradistinction to the PRC, and as a way of highlighting the injustice of Taiwan's exclusion from "official" international affairs. Democracy is a

Figure 5: Proportion of Taiwan Identity Language, by Audience

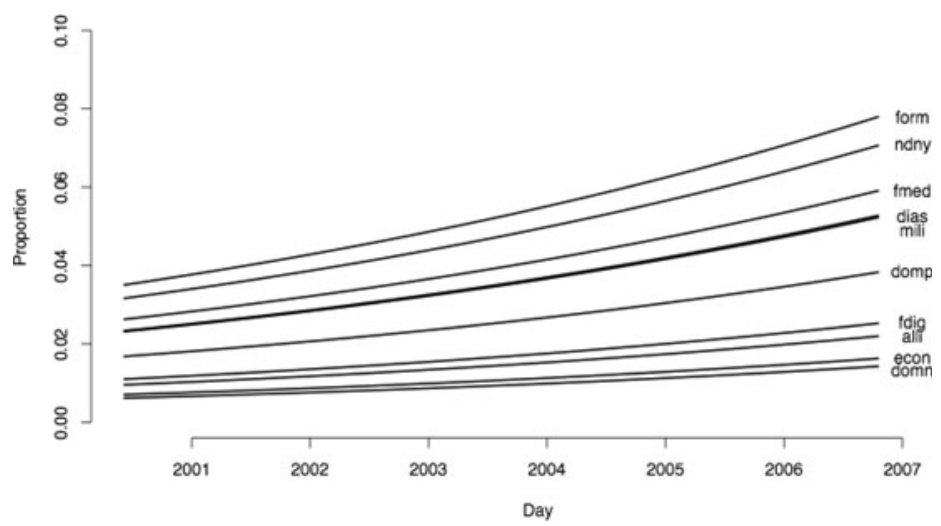




\section{Figure 6: Proportion of Democracy Language, by Audience}

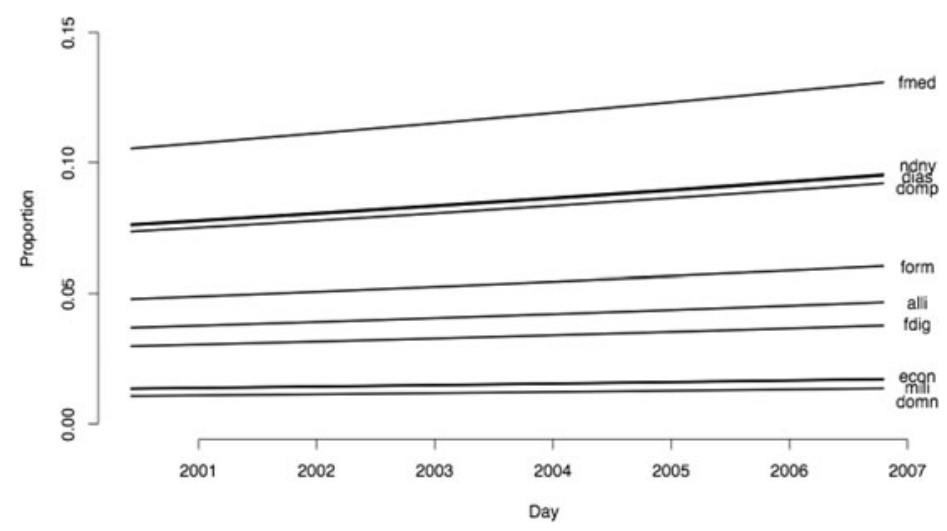

strong theme in New Year speeches and to pro-Taiwan support groups overseas and domestic political audiences.

\section{Conclusion}

We began this article by pointing out that Chen Shui-bian earned an international reputation as a dedicated promoter of "Taiwan independence" during his tenure as president of the ROC. Critiquing the tendency of the international media, and some scholars, to propagate this conventional and seldom questioned notion, we argued that a more useful approach to understanding Chen's rhetoric is to decompose cross-Strait discourse into its discursive component parts. Applying this approach to the analysis of over 2,000 of Chen's speeches, we arrived at empirical estimates of the comparative frequency and amount that Chen talks about sovereignty, national identity and democracy that challenge the conclusions of analyses based on a small number of selected speeches. ${ }^{78}$ Methodologically, we have demonstrated that systematic large-scale analysis reveals an alternative reading of Chen's rhetoric, which may be a useful complement to more detailed analyses. Substantively, we have shown that Chen addressed sovereignty, the category that contains the discursive markers most likely to connote independence, much less often and much less proportionally, than Taiwan identity, democracy or the economy. Moreover, the content of Chen's speeches, or more specifically Chen's emphasis on particular discursive categories, varied substantially and significantly according to the primary audience to whom he delivered the speech. For instance, foreign media and pro-Taiwan Diaspora groups were much more frequently exposed to sovereignty language than any other audience. This finding is of substantive importance for

78 Ross, "Explaining Taiwan's revisionist diplomacy"; Robert Ross, "Taiwan's fading independence movement," Foreign Affairs, Vol. 85, No. 2 (2006), pp. 141-48. 
638 The China Quarterly, 203, September 2010, pp. 619-638

both scholars and policy makers, since the strategic conditions faced by Chen are likely to influence ROC presidents for the foreseeable future. While exploration of the link between Chen's underlying preferences, strategic choices and rhetoric awaits further investigation, the findings presented here challenge conventional portrayals of former president Chen and provide a context for analysing democratic communication in Taiwan. 